\title{
Study in the Use of Organic Mulch and Varieties on Production Cabbage (Brassica oleraceae L.) at Different Altitude
}

\author{
Ramli, Fathurrahman, Iskandar M Lapanjang and Bahrudin \\ Department of Agriculture, University of Tadulako, Palu, Indonesia, 94118
}

\begin{abstract}
This study aims to assess the effect of various types and varieties of organic mulch on the quantity and quality of cabbage plants (Brassica oleraceae L.) at various altitudes. This research using Random Design Group (RDG) arranged as factorial by 2 factors. The first factor is testing four varieties of cabbage: V1 (KK-Cross), V2 (Grand 11), V3 (Silvia), V4 (Talents). The second factor is testing a variety of organic mulch: M0 (without mulch), M1 (rice straw mulch), M2 (rice husk mulch). The results showed that the KK Cross varieties have crop weight $(1226.11 \mathrm{~g})$ or 49 tons haa $^{-1}$ heavier than other varieties at an altitude of 110 meters above sea level. At an altitude of 400 meters above sea level Grand 11 Varieties resulted in crop weight $(1125.00 \mathrm{~g})$ or 45 ton ha $^{-1}$ is heavier than other varieties. Furthermore, at an altitude of 1350 meters above sea level Grand 11 varieties produce crop weight (1055.56 g) or 42.2 tons ha $^{-1}$ heavier than other varieties. 3). Rice straw mulch is better at producing crop volume $(985.25 \mathrm{ml})$ than other organic mulch treatment at an altitude of 110 meters above sea level. At an altitude of 400 above sea level rice husk mulch is better $(831.83 \mathrm{ml})$ in producing the crop volume and at an altitude of 1350 meters above sea level treatment without mulch is better ( $984.83 \mathrm{ml})$ in volume produces of crop compared to other treatments 4). Indicators of crispy on cabbage planted at an altitude of 110 meters above sea level is the Talent without mulch and mulch varieties of rice husks and varieties Grand 11 mulched straw and rice husks. At an altitude of 400 meters above sea level the crispy indicators are on the variety KK Cross with straw rice mulch. At an altitude of 1350 meters above sea level crispy indicators contained in all varieties that were given rice straw mulch and KK Cross varieties with rice husk mulch.
\end{abstract}

Keywords: Mulch, Quality, Quantity and Cabbage.

\section{INTRODUCTION}

Various studies of food consumption in general revealed that the consumption of vegetables and fruit per capita income has greater income elasticity than the food consumption of carbohydrates and the elasticity values are greater in households with higher income levels. That is, the economic development which has led to an increase in household income will lead to an increase in consumption per capita which is higher in vegetable varieties and fruit compared to carbohydrate foods.

The Increased per capita consumption is expected to be faster in urban areas than rural areas because the income elasticity of fruit and vegetable consumption tends to be higher in urban areas. This trend may occur because the income of the urban population is greater than the villagers and changing consumption patterns associated with social dynamics such an understanding of the nutrients in general are better in the city area.

That fact becomes initial data to be used as a benchmark in the development of cabbage commodity. This is corroborated by the results of the analysis of the World Bank in 1991, the demand for vegetables in Indonesia is projected to increase by 5 percent per year between 1998 and 2010. Cabbage plays an important role in the food industry of the country, because it can be processed into a variety of dishes from street food stalls to five star hotels.

The data of cabbage production in Central Sulawesi region in 2010 was 3.752 ton, in 2011 was 4,001 tons, in 2012 was 1,139 tons and in 2013 was decreased to 871 tons. Entering the year of 2014,the production rose to 8.510 tons (Central Bureau of Statistics and the Directorate General of Horticulture, 2014). The figure shows that the potential of this type of cabbage vegetable is still relatively high, it can be seen from the marketing distribution of cabbage from Palu can be marketed inter-islands such as to Kalimantan.

The figure shows that the potential of this type of cabbage is still relatively high, it can be seen from the high demand of this kind of vegetables from the sea food restaurants that spread in urban areas to the countryside. Besides, these kinds of vegetables are chosen by the inter-island traders as business commodities that possess high demand.

\section{MATERIALS AND METHODS}

\subsection{Time and Setting of Research}

This research was conducted at three different locations: The altitude of $110 \mathrm{~m}$ above sea level $\left(0,51^{0} 55^{\prime} 50\right.$ "South latitude and $119^{0} 19^{\prime} 21^{\prime \prime}$ east longitude, 110 meters above sea level), Altitude $400 \mathrm{~m}\left(1^{0} 58^{\prime} 53\right.$ "South latitude and $120^{\circ} 21^{\prime} 26^{\prime \prime}$ Longitude east, 400 meters above sea level) and at altitude of $1350 \mathrm{~m}$ above sea level $\left(1^{0} 6^{\prime} 44\right.$ "South Latitude and $120^{\circ} 55^{\prime} 07^{\prime}$ east longitude, $1350 \mathrm{~m}$ above sea level). The research was conducted from April to August 2014. 


\subsection{Design of Experiments and Technical Implementation}

Research using Random Group of Factorial pattern with 2 treatment factors, the first treatment is testing four varieties of cabbage: V1 (KK-Cross), V2 (Grand 11), V3 (Silvia), V4 (Talents). The second factor is the straw mulch treatment with levels: M0 (without mulch), M1 (rice straw mulch), M2 (rice husk mulch). The overall combination is 12 treatments with the total number of plots is 36 sample plots at each research site.

Data obtained during the observations were subsequently analyzed by analysis of variance and if there is a difference between the treatments then continued by Honestly Significant Difference Test (HSD) 5\%.

\section{RESULTS AND DISCUSSION}

\subsection{Number of leaves}

Table 1 show that the interaction between rice straw mulch and KK Cross varieties at altitude of $110 \mathrm{~m}$ above sea level produced the highest number of leaves (4.78). At an altitude of $400 \mathrm{~m}$ above sea level the grand 11 varieties which was given rice husk mulch have the highest number of leaves (5.44) compared to other treatments. While at an altitude of $1350 \mathrm{~m}$ above sea level, the variety of Talenta without mulch produced the highest number of leaves (4.67) compared to other treatments. The condition indicated that cabbage grown in lowland require micro climate conditions around the plants not to be overheat. Because it is known that at that age, the plants are still in the vegetative phase characterized by the formation of vegetative organs.

Solo Samosir and Ambo Ala (2002) suggests the young plants that grow well can develop roots more quickly to absorb nutrients available in the soil before the soil washed away or fixed. Sufficient supply of nutrients from the roots to the top of the plant can support the growth of the plant canopy. Plant canopy that grow faster can cover the ground earlier and directly influent in reducing water evaporation from the soil.

Gunasekera G.P. research results, (2006) explains that the early growth of cabbage is supported by a lower temperature because it will accelerate the rate of formation of the canopy, the interception of radiation and increase transpiration produces high dry material. Soil moisture surface layer is better preserved can increase nutrient uptake by plant roots. The above mentioned conditions supported with rice straw mulching brindle arranged between the crop rows double rows system. Rice straw mulch in this way is relatively thicker and denser so that its influence in conserving ground water and suppress weeds is greater.

Table 1. The Number of Leaves of 20 DAP Cabbage with Mulch Treatment and Varities in Various altitude.

\begin{tabular}{|c|c|c|c|c|c|c|}
\hline \multirow{2}{*}{ Altitude } & \multirow{2}{*}{ Mulch } & \multicolumn{4}{|c|}{ Varieties } & \multirow{2}{*}{ HSD $5 \%$} \\
\hline & & KK Cross & Grand 11 & Silvia & Talenta & \\
\hline \multirow{3}{*}{$\begin{array}{c}110 \mathrm{~m} \\
\text { above sea } \\
\text { level }\end{array}$} & Without Mulch & $3,56 \mathrm{a}$ & $3,78 \mathrm{a}$ & $3,78 \mathrm{a}$ & $3,44 \mathrm{a}$ & \multirow{3}{*}{0,96} \\
\hline & Rice straw mulch & $4,78 \mathrm{~b}$ & $3,67 \mathrm{a}$ & $3,56 \mathrm{a}$ & $4,00 \mathrm{ab}$ & \\
\hline & Rice husk mulch & $4,11 \mathrm{ab}$ & $3,89 \mathrm{ab}$ & $3,44 \mathrm{a}$ & $3,56 \mathrm{a}$ & \\
\hline \multirow{3}{*}{$\begin{array}{c}400 \mathrm{~m} \\
\text { above sea lvel }\end{array}$} & Without Mulch & $3,22 \mathrm{a}$ & $3,67 \mathrm{a}$ & $3,56 \mathrm{a}$ & $3,89 \mathrm{a}$ & \multirow{3}{*}{0,98} \\
\hline & Rice straw mulch & $3,67 \mathrm{a}$ & $4,11 \mathrm{a}$ & $4,11 \mathrm{a}$ & $3,78 \mathrm{a}$ & \\
\hline & Rice husk mulch & $3,48 \mathrm{a}$ & $5,44 \mathrm{~b}$ & $4,11 \mathrm{a}$ & $3,89 \mathrm{a}$ & \\
\hline \multirow{3}{*}{$\begin{array}{c}1350 \mathrm{~m} \text { above } \\
\text { sea level }\end{array}$} & Without Mulch & $3,67 \mathrm{a}$ & $5,00 \mathrm{c}$ & $3,44 \mathrm{a}$ & $4,67 \mathrm{bc}$ & \multirow{3}{*}{0,77} \\
\hline & Rice straw mulch & 3,33 a & $3,67 \mathrm{a}$ & $3,44 \mathrm{a}$ & $3,44 \mathrm{a}$ & \\
\hline & Rice husk mulch & $3,56 \mathrm{a}$ & $4,00 \mathrm{a}$ & $3,44 \mathrm{a}$ & $4,11 \mathrm{~b}$ & \\
\hline
\end{tabular}

Note : The number that accompanied by letter is similar to the similar rows are not significantly different at HSD 5\% Test.

\subsection{Leaf Area Index}

Leaf area index is a picture of the leaf surface area ratio of land occupied by crops growing. The growth rates of the plants are affected by the rate of net assimilation and leaf area index. The net assimilation rate is high and optimum leaf area index can improve plant growth. Increased leaf area in the absorption of $\mathrm{CO} 2$ for photosynthesis is supported by the structure of the leaves are ideal even in conditions of environmental stress is the ability of plants to adapt in order to remain sustainable (Gardner, et al., 1991). According to June (2003), Leaf is one of the most important organs of the plant. Leaves are the place for the photosynthesis process to draw up the plant dry materials.

Table 2 shows that the widest leaf area index for KK Cross varieties which were given rice straw mulch at an altitude of $110 \mathrm{~m}$ above sea level has relation to the number of leaves. This is consistent with Gomies et al. (2012) result research that the leaf area index is closely related to the number of leaves. Leaf is the main organ that functions in photosynthesis because the leaves have pigments that play a role in absorbing the sunlight. The energy of the Sunlight needed for the process plant growth and development of plants. The sunlight received by the leaves in large quantities will provide more leaves formation compared to the leaves that received fewer sunlight. 
Table 2. The 40 DAP Cabbage leaf area index As a result of mulch and Variety in Different Altitudes

\begin{tabular}{|c|c|c|c|c|c|c|}
\hline \multirow{2}{*}{ Altitudes } & \multirow{2}{*}{ Mulch } & \multicolumn{4}{|c|}{ Varieties } & \multirow{2}{*}{ HSD $5 \%$} \\
\hline & & KK Cross & Grand 11 & Silvia & Talenta & \\
\hline \multirow{3}{*}{$\begin{array}{c}110 \mathrm{~m} \\
\text { above sea level }\end{array}$} & Without Mulch & $0,46 \mathrm{a}$ & $0,44 \mathrm{a}$ & $0,42 \mathrm{a}$ & $0,41 \mathrm{a}$ & \multirow{3}{*}{0,05} \\
\hline & Rice straw mulch & $0,52 \mathrm{~b}$ & $0,42 \mathrm{a}$ & $0,41 \mathrm{a}$ & $0,43 \mathrm{a}$ & \\
\hline & Rice husk mulch & $0,45 \mathrm{a}$ & $0,44 \mathrm{a}$ & $0,43 \mathrm{a}$ & $0,43 \mathrm{a}$ & \\
\hline \multirow{3}{*}{$\begin{array}{l}400 \mathrm{~m} \\
\text { Above sea level }\end{array}$} & Without Mulch & $0,40 \mathrm{a}$ & $0,43 \mathrm{a}$ & $0,41 \mathrm{a}$ & $0,40 \mathrm{a}$ & \multirow{3}{*}{$\mathbf{0 , 0 7}$} \\
\hline & Rice straw mulch & $0,40 \mathrm{a}$ & $0,45 \mathrm{a}$ & $0,40 \mathrm{a}$ & $0,41 \mathrm{a}$ & \\
\hline & Rice husk mulch & $0,40 \mathrm{a}$ & $0,55 \mathrm{~b}$ & $0,41 \mathrm{a}$ & $0,41 \mathrm{a}$ & \\
\hline \multirow{3}{*}{$\begin{array}{c}1350 \mathrm{~m} \\
\text { Above sea level }\end{array}$} & Without Mulch & $0,42 \mathrm{a}$ & $0,59 \mathrm{~b}$ & $0,40 \mathrm{a}$ & $0,45 \mathrm{~b}$ & \multirow{3}{*}{$\mathbf{0 , 0 8}$} \\
\hline & Rice straw mulch & $0,36 \mathrm{a}$ & $0,42 \mathrm{a}$ & $0,38 \mathrm{a}$ & $0,40 \mathrm{a}$ & \\
\hline & Rice husk mulch & $0,40 \mathrm{a}$ & $0,43 \mathrm{a}$ & $0,41 \mathrm{a}$ & $0,41 \mathrm{a}$ & \\
\hline
\end{tabular}

Note : The number that accompanied by letter is similar to the similar rows are not significantly different at HSD 5\% Test.

\subsection{NAR and CGR}

The highest Value of net assimilation rate (Table 3) is on an altitude of $110 \mathrm{~m}$ above sea level on a variety of Talenta by using rice straw mulch and the lowest is at an altitude of $400 \mathrm{~m}$ above sea level on a variety of Talenta by using rice husk mulch. It is suspected that the rice straw mulch at altitude of $110 \mathrm{~m}$ above sea level have not been able to suppress a high temperature around the plant, causing the respiration rate is high compared to the Talenta variety of other treatments. By contrast, in an altitude of $400 \mathrm{~m}$ above sea level Talenta which were given rice husk mulch would have a low net assimilation value rate, it means that the response varieties of Talenta by using rice husk mulch is low in utilizing the temperature around the plant.

The growth rate of the plant is the plant's ability to produce dry ingredients result of assimilation per unit area per unit time $\left(\mathrm{g} \mathrm{cm}^{-2} \mathrm{day}^{-1}\right)$. The growth rate of the plants running at maximum speed when the temperature is at the optimum conditions (suitable), if other factors are not to be limiting (Jumin, 2002).

The result of the research (Table 4) showed that the varieties of KK Cross which were given rice straw mulch and planted at an altitude of $110 \mathrm{~m}$ above sea level, contributes a higher value on the growth rate of plants compared to other treatments. This indicates that rice husk mulch around the plant was able to maintain a good temperature for plant growth of KK Cross cabbage varieties grown at an altitude of $110 \mathrm{~m}$ above sea level. The results of research of Nkansah et al (2003) explains that mulching with organic materials rice husk able to maintain soil temperature and humidity around the plant compared to controls in tomato plants. Soil temperature and humidity suitable for KK Cross cabbage as shown by some researchers that the KK-Cross planted in climates between $18.6-26,9^{\circ} \mathrm{C}$ can have weight up to $2,52 \mathrm{~kg} \mathrm{crop}^{-1}$ (Nathoo, et al., 1998). The results of this research is also supported by the high net assimilation rate in KK Cross with rice straw mulch and rice husks mulch are no different from the varieties of Talenta at an altitude of $110 \mathrm{~m}$ above sea level.

Table 3. Net Assimilation Rate (NAR) 50 DAP $\left(\mathrm{g} \mathrm{cm}^{-2}\right.$ day $\left.^{-1}\right)$ Cabbage as result of mulch Application and Variety in Different Altitude

\begin{tabular}{|c|c|c|c|c|c|c|}
\hline \multirow{2}{*}{ Altitude } & \multirow{2}{*}{ Mulch } & \multicolumn{4}{|c|}{ Varieties } & \multirow{2}{*}{ HSD $5 \%$} \\
\hline & & KK Cross & Grand 11 & Silvia & Talenta & \\
\hline $110 \mathrm{~m}$ & Without Mulch & $0,0040 \mathrm{a}$ & $0,0042 \mathrm{a}$ & $0,0044 \mathrm{a}$ & $0,0050 \mathrm{a}$ & \multirow{3}{*}{0,0015} \\
\hline \multirow{2}{*}{$\begin{array}{c}\text { Above sea } \\
\text { level }\end{array}$} & Rice straw mulch & $0,0041 \mathrm{a}$ & $0,0042 \mathrm{a}$ & $0,0042 \mathrm{a}$ & $0,0066 \mathrm{~b}$ & \\
\hline & Rice husk mulch & $0,0043 \mathrm{a}$ & $0,0042 \mathrm{a}$ & $0,0042 \mathrm{a}$ & $0,0041 \mathrm{a}$ & \\
\hline $400 \mathrm{~m}$ & Without Mulch & $0,0040 \mathrm{ab}$ & $0,0037 \mathrm{ab}$ & $0,0037 \mathrm{ab}$ & $0,0038 \mathrm{ab}$ & \multirow{3}{*}{0,00096} \\
\hline \multirow{2}{*}{$\begin{array}{c}\text { Above sea } \\
\text { level }\end{array}$} & Rice straw mulch & $0,0036 \mathrm{ab}$ & $0,0038 \mathrm{ab}$ & $0,0038 \mathrm{ab}$ & $0,0038 \mathrm{ab}$ & \\
\hline & Rice husk mulch & $0,0044 \mathrm{~b}$ & $0,0037 \mathrm{ab}$ & $0,0036 \mathrm{ab}$ & $0,0031 \mathrm{a}$ & \\
\hline $1350 \mathrm{~m}$ & Without Mulch & $0,0040 \mathrm{a}$ & $0,0040 \mathrm{a}$ & $0,0038 \mathrm{a}$ & $0,0039 \mathrm{a}$ & \multirow{3}{*}{0,0082} \\
\hline \multirow{2}{*}{$\begin{array}{c}\text { Above sea } \\
\text { level }\end{array}$} & Rice straw mulch & $0,0040 \mathrm{a}$ & 0,0039 a & $0,0050 \mathrm{~b}$ & $0,0041 \mathrm{a}$ & \\
\hline & Rice husk mulch & $0,0040 \mathrm{a}$ & $0,0040 \mathrm{a}$ & $0,0041 \mathrm{a}$ & $0,0041 \mathrm{a}$ & \\
\hline
\end{tabular}

Note: The Number that Accompanied by letter is similar not significantly different at HSD 5\% Test. 
Tabel 4. Crop Growth Rate (CGR) 40 DAP $\left(\mathrm{g} \mathrm{cm}^{-2} \mathrm{day}^{-1}\right)$ Cabbage as result of Mulch Application and Varieties in different altitudes.

\begin{tabular}{|c|c|c|c|c|c|c|}
\hline \multirow{2}{*}{ Altitude } & \multirow{2}{*}{ Mulch } & \multicolumn{4}{|c|}{ Varieties } & \multirow{2}{*}{$\begin{array}{c}\text { HSD } \\
5 \%\end{array}$} \\
\hline & & KK Cross & Grand 11 & Silvia & Talenta & \\
\hline $110 \mathrm{~m}$ & Without Mulch & $3,7 \times 10^{-5} \mathrm{~b}$ & $3,4 \times 10^{-5} \mathrm{ab}$ & $3,1 \times 10^{-5} \mathrm{ab}$ & $2,5 \times 10^{-5} \mathrm{a}$ & \multirow{3}{*}{$1,0 \times 10^{-5}$} \\
\hline \multirow{2}{*}{$\begin{array}{c}\text { Above sea } \\
\text { level }\end{array}$} & Rice straw mulch & $5,3 \times 10^{-5} \mathrm{c}$ & $3,3 \times 10^{-5} \mathrm{ab}$ & $3,4 \times 10^{-5} \mathrm{ab}$ & $3,2 \times 10^{-5} \mathrm{ab}$ & \\
\hline & Rice husk mulch & $4,0 \times 10^{-5} \mathrm{bc}$ & $3,5 \times 10^{-5} \mathrm{ab}$ & $3,3 \times 10^{-5} \mathrm{ab}$ & $2,9 \times 10^{-5} \mathrm{ab}$ & \\
\hline $400 \mathrm{~m}$ & Without Mulch & $2,3 \times 10^{-5}$ a & $2,5 \times 10^{-5} \mathrm{a}$ & $2,6 \times 10^{-5} \mathrm{a}$ & $2,5 \times 10^{-5} \mathrm{a}$ & \multirow{3}{*}{$8,0 \times 10^{-5}$} \\
\hline \multirow{2}{*}{$\begin{array}{c}\text { Above sea } \\
\text { level }\end{array}$} & Rice straw mulch & $2,4 \times 10^{-5} \mathrm{a}$ & $3,1 \times 10^{-5} \mathrm{ab}$ & $2,8 \times 10^{-5} \mathrm{ab}$ & $2,7 \times 10^{-5} \mathrm{a}$ & \\
\hline & Rice husk mulch & $2,4 \times 10^{-5} \mathrm{a}$ & $3,6 \times 10^{-5} \mathrm{~b}$ & $2,8 \times 10^{-5} \mathrm{ab}$ & $2,8 \times 10^{-5} \mathrm{ab}$ & \\
\hline $1350 \mathrm{~m}$ & Without Mulch & $2,3 \times 10^{-5} \mathrm{a}$ & $2,8 \times 10^{-5} \mathrm{ab}$ & $2,5 \times 10^{-5} \mathrm{a}$ & $3,3 \times 10^{-5} \mathrm{~b}$ & \multirow{3}{*}{$6,0 \times 10^{-5}$} \\
\hline \multirow{2}{*}{$\begin{array}{c}\text { Above sea } \\
\text { level }\end{array}$} & Rice straw mulch & $2,5 \times 10^{-5} \mathrm{a}$ & $2,6 \times 10^{-5} \mathrm{a}$ & $2,6 \times 10^{-5} \mathrm{a}$ & $2,7 \times 10^{-5} \mathrm{a}$ & \\
\hline & Rice husk mulch & $2,6 \times 10^{-5} \mathrm{a}$ & $2,6 \times 10^{-5} \mathrm{a}$ & $2,7 \times 10^{-5} \mathrm{a}$ & $2,5 \times 10^{-5} \mathrm{a}$ & \\
\hline
\end{tabular}

\subsection{The Age at Harvest}

The types of rice straw mulch and rice husk influence the age at harvest (Table 5) KK Cross and Grand 11 varieties are faster in every research location. This shows that both varieties are able to respond to the range of temperatures that exist around the plant were given rice husk mulch, while the temperature range around the plants by applying the rice straw mulch and rice husk mulch was $26.74^{\circ} \mathrm{C}$ at an altitude of $110 \mathrm{~m}$ above sea level, $28.28^{\circ} \mathrm{C}$ in an altitude of $400 \mathrm{~m}$ above sea level and $25.04^{\circ} \mathrm{C}$ at an altitude of $1350 \mathrm{~m}$ above sea level. According to Dainello F.J et al (2009), the use of rice husk mulch and rice straw mulch on the cultivation of cabbage in hot climates will support faster crop harvest time than the use of solid and plastic mulch. But even better is rice husk mulch, it is due to the nature of rice husk mulch more nests than rice straw mulch. The soil moisture under the mulch nest is lower than the soil moisture under dense mulch.

Table 5. The Age At Harvest of Cabbage (days) As a result of Mulch treatment and Variety in Different Altitude.

\begin{tabular}{clccccc}
\hline \multirow{2}{*}{ Altitudes } & \multirow{2}{*}{ Mulch } & \multicolumn{2}{c}{ Varietas } & HSD \\
\cline { 2 - 5 } & & KK Cross & Grand 11 & Silvia & Talenta & $\mathbf{5} \%$ \\
\hline $110 \mathrm{~m}$ & Without Mulch & $70,00 \mathrm{bcd}$ & $72,00 \mathrm{~cd}$ & $73,00 \mathrm{~cd}$ & $74,00 \mathrm{~d}$ & \\
Above sea & Rice straw mulch & $57,00 \mathrm{a}$ & $66,67 \mathrm{~b}$ & $68,33 \mathrm{bc}$ & $67,67 \mathrm{bc}$ & $\mathbf{5 , 5 3}$ \\
level & Rice husk mulch & $66,00 \mathrm{~b}$ & $67,67 \mathrm{bc}$ & $70,00 \mathrm{bcd}$ & $72,00 \mathrm{~cd}$ & \\
\hline $400 \mathrm{~m}$ & Without Mulch & $73,67 \mathrm{~b}$ & $68,00 \mathrm{ab}$ & $70,33 \mathrm{~b}$ & $70,00 \mathrm{~b}$ & \\
Above sea & Rice straw mulch & $73,67 \mathrm{~b}$ & $69,67 \mathrm{ab}$ & $68,33 \mathrm{ab}$ & $70,33 \mathrm{~b}$ & $\mathbf{7 , 8 6}$ \\
level & Rice husk mulch & $73,33 \mathrm{~b}$ & $56,00 \mathrm{a}$ & $66,67 \mathrm{ab}$ & $69,67 \mathrm{ab}$ & \\
\hline $1350 \mathrm{~m}$ & Without Mulch & $70,67 \mathrm{bc}$ & $64,33 \mathrm{~b}$ & $68,00 \mathrm{bc}$ & $67,67 \mathrm{bc}$ & \\
Above sea & Rice straw mulch & $72,67 \mathrm{c}$ & $66,33 \mathrm{bc}$ & $69,33 \mathrm{bc}$ & $68,33 \mathrm{bc}$ & $\mathbf{7 , 6 4}$ \\
level & Rice husk mulch & $70,33 \mathrm{bc}$ & $55,33 \mathrm{a}$ & $71,67 \mathrm{bc}$ & $68,00 \mathrm{bc}$ & \\
\hline
\end{tabular}

Note : The Number that Accompanied by letter is similar to the similar rows are not significantly different at HSD 5\% Test.

\subsection{The Wet Weight of Crop}

Effect of rice straw mulch treatments able to produce the highest crop wet weight and significantly different from those without mulch varieties KK Cross altitude 110 meters above sea level (lowlands) of $1226.67 \mathrm{~g}$ equivalent to 49 ton $\mathrm{ha}^{-1}$ exceeds the production the description, but not different rice husk mulch. It is suspected of rice straw mulch able to maintain micro-climatic conditions (soil temperature) so that helps plants absorb nutrients properly. The condition has also been proved by Edyta Koesterna (2014) who found their real effect of rice straw mulch 20 ton ha $^{-1}$ compared with no straw mulch on the observation of wet weight of broccoli planted at different times.

Furthermore, rice husk mulch provides the highest wet weight crop varieties altitude of 400 meters above sea Grand 11 (middle plains) of 1125.00 g equivalent to 45 ton ha $^{-1}$ and was significantly different from other treatments. These results suggested that the ability of mulch to retain soil temperature and moisture better than rice straw mulch at medium altitude. It can be seen in the field that rice husk mulch cover more equal than rice straw mulch on the experimental plot. Biological research results Erita et al., (2010) found that rice husk mulch real influence on all components of the production of maize crops were planted at an altitude of $500 \mathrm{~m}$ above sea level.

Treatment without mulch altitude of 1350 meters above sea level it produces a wet weight of the highest crop varieties Grand 11 amounted to $1055.67 \mathrm{~g}$ equivalent to 42 ton $^{-1} \mathrm{a}^{-1}$ but not significantly different from other 
mulch treatments. This indicates that at high altitude the temperature range in treatment without mulch seen in figure 1 is able to donate the proceeds to the Grand 11 varieties better than the temperature in other mulch treatment. Weight loss wet crop in cold regions, especially at higher elevations have also been raised by Rodriquez (2015) which states that the cabbage plant that grows in the cold temperature will cause a decrease in the wet weight of the crop by $50 \%$.

Table 6. The Average Crop Wet Weight (g) As a result of Mulch Treatment and Variety in Different Altitude.

\begin{tabular}{clccccc}
\hline \multirow{2}{*}{ Altitude } & \multirow{2}{*}{ Mulch } & \multicolumn{4}{c}{ Varieties } & HSD \\
\cline { 3 - 5 } & & KK Cross & Grand 11 & Silvia & Talenta & $\mathbf{5} \%$ \\
\hline $110 \mathrm{~m}$ & Without Mulch & $1117,00 \mathrm{~b}$ & $783,33 \mathrm{a}$ & $897,00 \mathrm{a}$ & $833,33 \mathrm{a}$ & \\
Above sea & Rice straw mulch & $1226,67 \mathrm{~b}$ & $1191,33 \mathrm{~b}$ & $900,00 \mathrm{a}$ & $805,00 \mathrm{a}$ & $\mathbf{2 8 2 , 7 9}$ \\
level & Rice husk mulch & $1176,33 \mathrm{~b}$ & $918,00 \mathrm{a}$ & $881,33 \mathrm{a}$ & $813,33 \mathrm{a}$ & \\
\hline $400 \mathrm{~m}$ & Without Mulch & $883,33 \mathrm{ab}$ & $958,33 \mathrm{abc}$ & $866,67 \mathrm{ab}$ & $816,67 \mathrm{a}$ & \\
Above sea & Rice straw mulch & $800,00 \mathrm{a}$ & $956,67 \mathrm{abc}$ & $1031,67 \mathrm{~cd}$ & $893,00 \mathrm{ab}$ & $\mathbf{1 7 0 , 6 5}$ \\
level & Rice husk mulch & $877,78 \mathrm{ab}$ & $1125,00 \mathrm{~d}$ & $968,33 \mathrm{abc}$ & $995,00 \mathrm{bc}$ & \\
\hline $1350 \mathrm{~m}$ & Without Mulch & $833,69 \mathrm{ab}$ & $1055,67 \mathrm{c}$ & $950,00 \mathrm{bc}$ & $1050,00 \mathrm{c}$ & \\
Above sea & Rice straw mulch & $666,67 \mathrm{a}$ & $993,33 \mathrm{bc}$ & $676,67 \mathrm{a}$ & $983,33 \mathrm{bc}$ & $\mathbf{2 3 2 , 5 0}$ \\
level & Rice husk mulch & $750,00 \mathrm{ab}$ & $1033,33 \mathrm{c}$ & $893,35 \mathrm{ab}$ & $789,00 \mathrm{ab}$ & \\
\hline
\end{tabular}

Note : The Number that Accompanied by letter is similar to the similar coloum are not significantly different at HSD 5\% Test.

\subsection{The Crop Volume}

The highest crop volume $(985.25 \mathrm{ml})$ is contained in rice straw mulch treatment at an altitude of $110 \mathrm{~m}$ above sea level, at an altitude of $400 \mathrm{~m}$ above sea level the highest crop volume $(831 \mathrm{ml})$ is contained in the rice husk mulch treatment and at an altitude of $1350 \mathrm{~m}$ above sea level the highest crop volume $(984,83 \mathrm{ml})$ is on treatment without mulch. The treatment of KK Cross and Grand 11 varieties resulting in highest crop volume in altitude $110 \mathrm{~m}$ above sea level, Bobo and Wino Wanga and significantly different from other treatments. It is suspected that both varieties suitable for the formation of the volume of the crop in the highlands (Bobo and Wino Wanga), whereas KK Cross variety is appropriate in low-lying areas (Jono Oge) as shown in the release of hybrid varieties in the Decree of the Minister of Agriculture Number: 337 / Kpts / SR. 120 / 5/2006 and No. 390 / Kpts / SR.120 / 10/2005).

Table 7. Volume of Cabbage (ml) As a result of Mulch Treatment and Variety in Different Altitude

\begin{tabular}{|c|c|c|c|}
\hline \multirow[b]{2}{*}{ Treatment } & \multicolumn{3}{|c|}{ Crop Volume } \\
\hline & $\begin{array}{c}110 \mathrm{~m} \\
\text { above sea level }\end{array}$ & $\begin{array}{c}400 \mathrm{~m} \\
\text { above sea level }\end{array}$ & $\begin{array}{c}1350 \mathrm{~m} \\
\text { above sea level }\end{array}$ \\
\hline Without Mulch & $833,17 \mathrm{a}$ & $694,58 \mathrm{a}$ & $984,83 \mathrm{~b}$ \\
\hline Rice straw mulch & $985,25 \mathrm{~b}$ & $766,58 \mathrm{ab}$ & $873,75 \mathrm{a}$ \\
\hline Rice husk mulch & $911,17 \mathrm{ab}$ & $831,83 \mathrm{~b}$ & $941,67 \mathrm{ab}$ \\
\hline HSD 5\% & 90,18 & 100,35 & 68,95 \\
\hline KK Cross & $1092,11 \mathrm{c}$ & $514,44 \mathrm{a}$ & $775,00 \mathrm{a}$ \\
\hline Grand 11 & $938,44 \mathrm{~b}$ & $1053,44 \mathrm{~d}$ & $1111,11 \mathrm{~d}$ \\
\hline Silvia & $879,22 \mathrm{~b}$ & $820,00 \mathrm{c}$ & $897,22 \mathrm{~b}$ \\
\hline Talenta & $730,00 \mathrm{a}$ & $669,44 \mathrm{~b}$ & $950,33 \mathrm{c}$ \\
\hline HSD $5 \%$ & 125,73 & 139,91 & 96,14 \\
\hline
\end{tabular}

\subsection{The Total of Plant Dry Weight}

The high total dry weight of cabbage plants (Table 8) planted at an altitude of $400 \mathrm{~m}$ above sea level using a mulch of rice husk indicates that the use of mulch can keep the moisture in the soil where plants grow in the lowlands so as to generate a total weight of cabbage plants are high, the main varieties in accordance with the terms grew desired. According to Noorhadi and Sudadi (2003) quoted by Nurheni Vitello and Nurunnajah (2010) the air and soil moisture, the temperature of air and soil plants, and each relating to realize the optimal environmental conditions for plants. As stated by (Wade et al. 1983 and Harith, 2000) that the mulch of rice straw on the soil surface in addition to functioning as an organic material, it can also improve the physical, chemical and biological soil in order to obtain the resistance of nutrients and water, improve soil structure, lowering the temperature of the soil, reducing excessive evaporation, reduce weeds and reduce erosion while straw mulch with its nature that easily weathered thus improving soil fertility. 
Table 8. The Total of Plant Dry Weight (g) As a result of Mulch Treatment Mulch and Variety in Different Altitude.

\begin{tabular}{lccc}
\hline \multirow{2}{*}{ Treatment } & \multicolumn{3}{c}{ The Total of Plant Dry Weight } \\
\cline { 2 - 4 } & $\begin{array}{c}110 \mathrm{~m} \\
\text { above sea level }\end{array}$ & $\begin{array}{c}400 \mathrm{~m} \\
\text { above sea level }\end{array}$ & $\begin{array}{c}1350 \mathrm{~m} \\
\text { above sea level }\end{array}$ \\
\hline Without Mulch & 272,30 & $199,88 \mathrm{a}$ & $252,88 \mathrm{~b}$ \\
Rice straw mulch & 350,99 & $217,41 \mathrm{a}$ & $209,70 \mathrm{a}$ \\
Rice husk mulch & 284,79 & $285,42 \mathrm{~b}$ & $192,17 \mathrm{a}$ \\
\hline \multicolumn{1}{c}{ HSD 5\% } & & 52,02 & 42,49 \\
\hline KK Cross & $420,00 \mathrm{c}$ & $130,60 \mathrm{a}$ & $147,86 \mathrm{a}$ \\
Grand 11 & $329,01 \mathrm{~b}$ & $373,25 \mathrm{c}$ & $313,11 \mathrm{c}$ \\
Silvia & $260,07 \mathrm{ab}$ & $264,97 \mathrm{~b}$ & $180,84 \mathrm{a}$ \\
Talenta & $201,69 \mathrm{a}$ & $168,11 \mathrm{a}$ & $231,18 \mathrm{~b}$ \\
\hline \multicolumn{1}{c}{ HSD 5\% } & 94,33 & 72,53 & 59,25 \\
\hline
\end{tabular}

Note : The Number that Accompanied by letter is similar to the similar coloum are not significantly different at HSD 5\% Test.
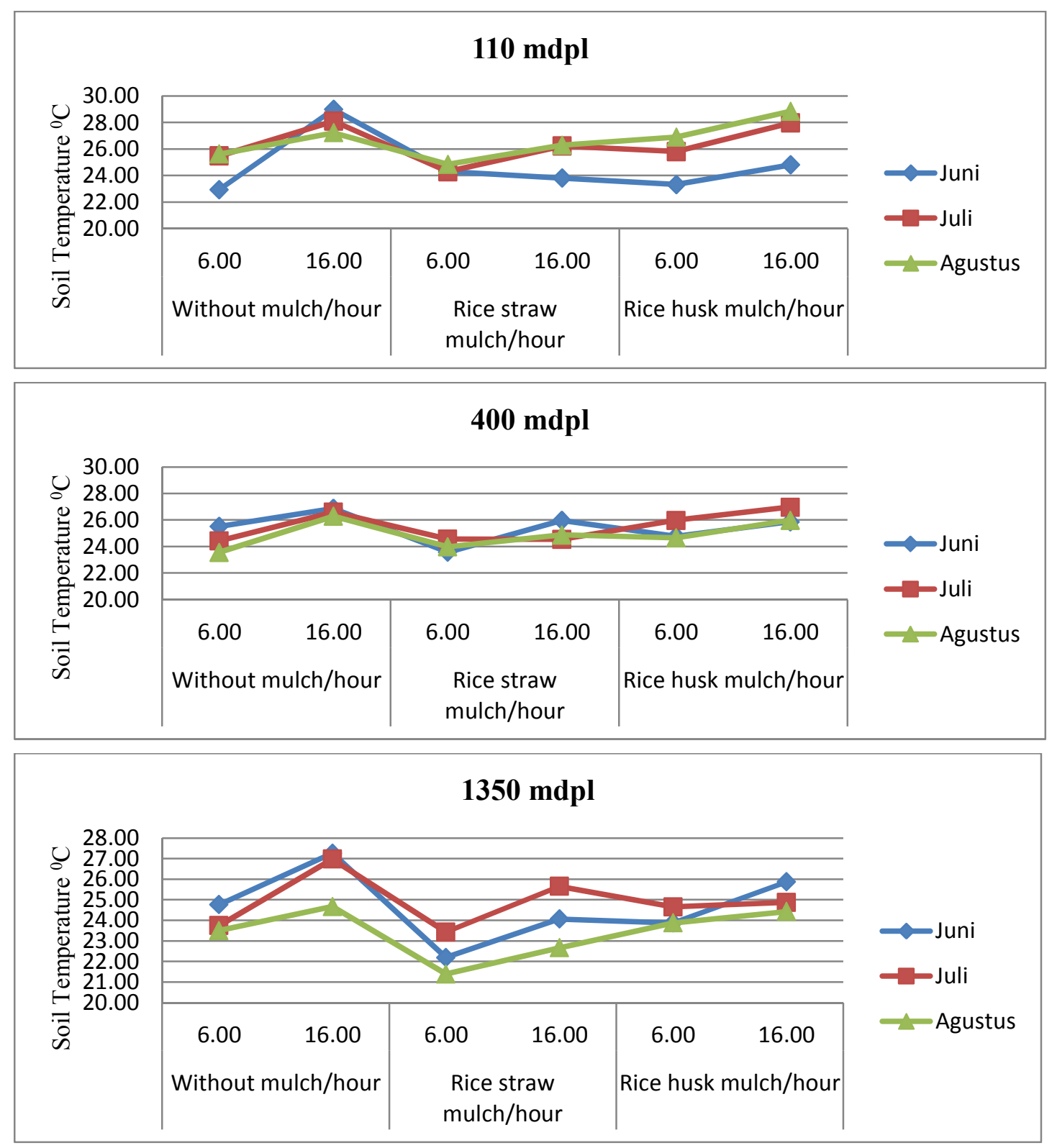

Figure 1. The soil temperature fluctuations at various altitude research 


\section{CONCLUSION}

The KK Cross variety has weighs crop of $1226.11 \mathrm{~g}\left(49\right.$ ton $\left.^{-1} \mathrm{a}^{-1}\right)$ heavier than the other varieties at an altitude of $110 \mathrm{~m}$ above sea level. At an altitude of $400 \mathrm{~m}$ above sea level the Grand 11 variety produce weight crop of $1125.00 \mathrm{~g}$ ( 45 ton $\mathrm{ha}^{-1}$ ) heavier than the other varieties. Furthermore, at an altitude of $1350 \mathrm{~m}$ above sea level Grand 11 variety produces weight crop of $1055.56 \mathrm{~g}$ ( 42.2 ton $\left.\mathrm{ha}^{-1}\right)$ heavier than the other varieties. Rice straw mulch on Grand 11 variety is better $(1081.44 \mathrm{ml})$ in producing the volume of crop compared to other treatments.

\section{REFERENCES}

Agustina, L., Syekhfani dan P. Enggariyanto, (2004). Penentuan dosis pupuk organik. Universitas Brawijaya. Malang. h. 5-9.

Bones, A.M., Rossiter, J.T., (1996). The myrosinase-glucosinolate system - an innate defense system in plants. Physiologia plantarum 97 (1): 194-208.

Dainello F.J and Roland Roberts, (2009). Cultural Practices Cabbage Chapter IV. Aggi Horticulture. Vegetable Resource. Htm.

Das, S., Tyagi, A.K., Kaur, H., (2000). Cancer modulation by glucosinolates: A review. Current Science 79 (12): $1665-1671$.

Edyta Koesterna, (2014). The yield and quality of broccoli grown under flat covers with soil mulching. Vol. 60, 2014, No. 5: 228-233 Plant Soil Environ Soil Mulching With Straw In Broccoli Cultivation For Early Harvest Journal of Ecological Engineering Volume 15, No. 2, April 2014, pp. 100-107 DOI: $10.12911 / 22998993.1094985$

Erita Hayati, A. Halim Ahmad \& Cut Taisir Rahman, (2010). Respons Jagung Manis (Zea mays, Sacharata SHOUT) Terhadap Penggunaan Mulsa dan Pupuk Organik. Jurnal Agrista Vol. 14 No. 1

Gardner, F.P., R.B. Pearce dan R.L. Mitchell, (1991). Fisiologi Tanaman Budidaya. Universitas Indonesia, Jakarta. h. 38-50.

Gunasekera, C.P., (2006). Genotype by environment interactions of Indian mustard (Brassica juncea L.) and canola (B. napus L.) in Mediterranean-type environments 1. Crop growth and seed yield. / Europ. J. Agronomi 25 (2006) 1-12.

Gomies, L., H. Rehatta, dan J. Nandissa, (2012). Pengaruh Pupuk Organik Cair RI1 Terhadap Pertumbuhan dan Produksi Tanaman Kubis Bunga (Brassica oleraceae var. botrytis L.). J. Agrologia, 1 (1) : 13-20

Jumin, H.B., (2002). Agroekologi Suatu Pendekatan Fisiologis. Radja Grafindo, Jakarta. h. 14-44.

KepMenTan Nomor : 390/Kpts/SR.120/10/2005. Tentang Pelepasan Kubis Hibrid Grand 11 Sebagai Varietas Unggul. Jakarta 31 Oktober 2005.

KepMenTan Nomor: 337/Kpts/SR.120/5/2006. Tentang Pelepasan Kubis Hibrid KK Cross Sebagai Varietas Unggul. Jakarta 4 Mei 2006.

Nathoo M., R. Nowbuth dan CL. Cangy. (1998). Brassica production introduction and evaluation of varieties. Amas. Food Agriculture Research Council, Reduit, Mauritius. h. 167-173.

Nkansah, GO, Owusu, EO, Bonsu, KO dan Dennis, EA., (2003). Pengaruh Jenis mulsa terhadap pertumbuhan, hasil dan kualitas buah tomat ( Lycopersicon esculentum Mill). Ghana Journal of Hortikultura . 3: 55-64.

Nurheni Wijayanto and Nurunnajah. (2010). Light Intensity, Temperature, Humidity and Rooting System of Mahogany (Swietenia macrophylla King.) in RPH Babakan Madang, BKPH Bogor, KPH Bogor. Jurnal Silvikultur Tropika Vol. 03 No. 01 April 2012, Hal. 8 - 13

Rodríguez, Víctor M. Rodríguez, Pilar Soengas, Virginia Alonso Villaverde, Tamara Sotelo, María E. Cartea and Pablo Velasco, (2015). Effect of temperature stress on the early vegetative development of Brassica oleraceae L. BMC Plant Biology 15:145

Rubatzky,V.E dan Yamaguchi,. (1998). (Sayuran Dunia, Prinsip, Produksi, dan Gizi, alih bahasa Catur Herison).ITB, Bandung.

Setyadjit dan Sjaifullah, (1994). Penyimpanan buah manggis dalam suhu dingin. J. Hort., vol. 4 no. 1. Hlm 6467.

Solo S.R. Samosir dan Ambo Ala. (2002). Pengelolaan Mulsa Jerami Padi dan Pemupukan Lewat Daun dan Pengaruhnya Terhadap Produksi Kedelai di Lahan Sawah. J. Sains \& Teknologi, April 2004, Vol. 4 No. 1:9-19

Wade MK. and PA. Sanchez. (1983). Mulching and green manure apllication for continous crop. Production in Amazon Basic. J.Agronomy. 2 (75) : 39-45. 